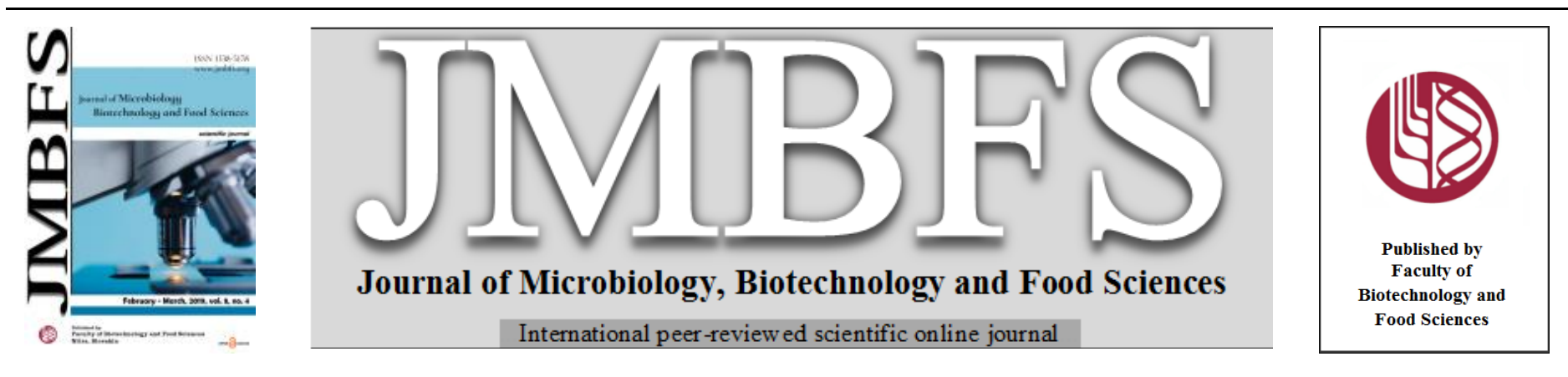

\title{
THE INFLUENCE OF VARIETY ON THE CONTENT OF BIOACTIVE COMPOUNDS IN GARLIC (ALLIUM SATIVUM
} L.)

\author{
Marianna Micová* ${ }^{*}$, Dana Urminská2, Judita Bystrickál, Ján Kovarovičl ${ }^{1}$ Luboš Harangozo ${ }^{1}$
}

Address(es): Ing. Marianna Micová,

${ }^{1}$ Slovak University of Agriculture in Nitra, Faculty of Biotechnology and Food Sciences, Department of Chemistry, Tr. A. Hlinku 2, 94976 Nitra, phone number: +421 376414375 .

${ }^{2}$ Slovak University of Agriculture in Nitra, Faculty of Biotechnology and Food Sciences, Department of Biochemistry and Biotechnology, Tr. A. Hlinku 2, 94976 Nitra.

*Corresponding author: xlenkova@is.uniag.sk

doi: 10.15414/jmbfs.2019.8.4.1076-1079

\section{ARTICLE INFO}

Received 9. 10. 2018

Revised 15. 11. 2018

Accepted 15. 11. 2018

Published 1. 2. 2019

Regular article

OPEN $\partial_{\text {ACCESS }}$

\begin{abstract}
Garlic (Allium sativum L.) is the most important species of the Allium genus and an important vegetable crop throughout the world. Garlic is widely used as an obligatory part in many cooked dishes. It is one of the ancient plants playing one of the most important dietary and medicinal roles in human beings for centuries. Garlic possess many therapeutic properties including antimicrobial, antiviral, antifungal, cardioprotective, neuroprotective, anticarcinogenic, antimutagenic, anti-hypertensive, anti-diabetic and antioxidant. This study has focused on the comparison of the total polyphenols content, the total sulphur content and antioxidant activity of the studied varieties of garlic in the area of Nitra, Slovak Republic. The analyzed samples of garlic were collected at the stage of full maturity. TPC was measured using the spectrophotometric method of Folin-Ciocalteu agents. TPC in studied varieties of garlic were determined in the range $742 \mathrm{mg} \cdot \mathrm{kg}^{-1}$ (Mojmír) to $635 \mathrm{mg} \cdot \mathrm{kg}^{-1}$ (Makoi). The determination of the total sulfur content was based on dry combustion in the presence of oxygen and allows for the quantitative conversion of sulfur to $\mathrm{SO}_{2}$. Statistically significant highest level of TSC recorded in $0.751 \%$ (Mojmír) and the lowest level was in $0.523 \%$ (Makoi). Antioxidant activity was determined by the spectrophotometric method using a compound $\mathrm{DPPH}^{*}$ (2.2-diphenyl-1-picryhydrazyl). The highest value of AA was measured in Mojmír (17.7\%). The lowest level was observed in Makoi (12.4\%). In all studied samples of garlic was confirmed by the strong dependence of the total polyphenols content, total sulfur content and antioxidant activity.
\end{abstract}

Keywords: antioxidant activity, garlic, polyphenols, sulphur compounds

\section{INTRODUCTION}

Garlic (Allium sativum L.) botanically a member of the Lillaceae family and Allium genus, is considered to be rich in medicinal properties (Amarakoon and Jayasekara, 2017). Garlic is used in medicines and foodstuff for almost three thousand years as evidenced by ancient writings from China, Egypt, Greece, and India (Cardelle-Cobas et al., 2010). Garlic bulb contains water (65\%), carbohydrates (28\%), organosulfur compounds (2.3\%), proteins (mostly allinase; $2 \%$ ), amino acids (1.2\%) and fiber (1.5\%) (Divya et al., 2017). Garlic is a source of various biologically active phytomolecules, including organosulfur compounds, phenolic acids, allyl thiosulfinates, flavonoids, vitamins and minerals (Chen et al., 2013). Garlic contains minerals like germanium, calcium, copper, iron, potassium, magnesium, selenium and zinc, vitamins $\mathrm{A}, \mathrm{B}_{1}$ and $\mathrm{C}$, fibre and water (Gebreselema and Mebrahtu, 2013).

A health property of garlic depends up on the bioactive compounds especially the organosulfur compounds, which are also responsible for the pungent flavor of garlic (Rahman, 2007; Tepe et al., 2005). Garlic contains more than one hundred biologically useful secondary metabolites, which include alliin, alliinase, allicin, S-allyl cysteine (SAC), diallyldisulphide (DADS), diallyltrisulphide (DATS) and methyl allyl trisulphide. The $\gamma$-glutamyl-S-alk(en)yl-L-cysteines are the primary sulfur compounds present in garlic. These active compounds are responsible for protection of tissue from damage and various disorders (Divya $\boldsymbol{e}$ al., 2017). The undamaged bulbs contain alliin which will be enzymatically converted to allicin during cutting. Allicin, is the major bioactive compound found in garlic followed by other organosulfur compounds (Amarakoon and Jayasekara, 2017).

The health properties of garlic depend on its bioactive compounds and especially on phenolic compounds, which have interesting pharmacological properties, are present in relatively high amounts (Chen et al., 2013). Phenolic compounds are large groups of secondary metabolites that are able to neutralize or quench the free radicals. Flavonoids and their derivatives are the largest group of polyphenols found in plants (Hounsome et al., 2009). The content of phenolic compounds in garlic thus varies greatly with genetic, agronomic, and environmental factors, and it is well known that cultivar is the primary factor that determines this variation (Chen et al., 2013).

The antioxidants are substances that delays, prevents or removes oxidative damage to a target molecule. Antioxidants are an inhibitor of the process of oxidation, even at relatively small concentration and thus have diverse physiological role in the body. A variety of free radical scavenging antioxidants is found in dietary sources like fruits, vegetables and tea (Yadav et al., 2016) The antioxidant potential of garlic in vivo and in vitro has been proved. Biochemical studies have demonstrated that garlic acts as antioxidant to protect cells against reactive oxygen species (ROS) (Chung, 2006).

Garlic show a wide range of beneficial health effects to treat various infectious diseases, non-communicable diseases as well as metabolic and genetic disorders. An overview is provided on the numerous clinical and experimental investigations done on the reduction of LDL cholesterol level, cardiovascular disease, blood glucose levels by garlic derivative compounds (Amarakoon and Jayasekara, 2017). The therapeutic potential of this plant product inhibits invasion of carcinoma, provides cardiovascular protection, lowering of cholesterol and blood pressure, anti-platelet activities, and thromboxane formation. In addition the biological activities of garlic include antibacterial, antithrombotic, antioxidant, immunomodulatory, antidiabetic and modulation of drug metabolism. The other proposed uses of garlic include hepatoprotection, anthelminthic, antiinflammation, antifungal and wound healing (Divya et al., 2017).

This study was designed to determine the variability in the content of total polyphenols, sulfur compounds and antioxidant capacity in variety of garlic cultivars. 


\section{MATERIAL AND METHODS}

\section{The local climate conditions}

This study was performed in area of Nitra, Slovak Republic. Nitra is situated on the south-western Slovakia in the area of Podunajská lowland. Nitra belongs to warmer and dry areas with mild winters in Slovakia. The average annual rainfall is $550-600 \mathrm{~mm}$ and the average annual temperature is $9-10^{\circ} \mathrm{C}$. Nitra have very good natural and climatic conditions for crop growth, without any adverse effects.

\section{Samples of plant material}

The samples of plant material (4 variety of garlic - Mojmír, Záhorský, Anton, Makoi) were collected in the phase of full ripeness from area of Nitra, Slovak republic. For analysis was used fresh material soil samples and plant. Samples were analysed by selected methodologies (determination of total polyphenols, total sulphur compounds and antioxidant activity). All samples of plant materia were grown under the same conditions. The soil samples from the area, where was grown plant material, was analysed (Table 1 and Table 2). The analysis of soil samples was carried out four times in four sampling sites with pedological probe Geosampler Fisher. Only NPK fertilization $\left(200 \mathrm{~g} \mathrm{per}^{2}\right)$ was used for the achievement of favourable soil macroelements content.

Table 1 Agrochemical characteristic of soil substrate in mg. $\mathrm{kg}^{-1}$, content of nutrients from locality Nitra

\begin{tabular}{lccccccc}
\hline Locality & $\mathbf{K}$ & $\mathbf{C a}$ & $\mathbf{M g}$ & $\mathbf{P}$ & $\mathbf{p H}_{\mathbf{K C l}}$ & Humus \% & Cox \% \\
\hline Nitra & $388.2 \pm 2.2$ & $3601.2 \pm 5.3$ & $825.0 \pm 2.8$ & $112.5 \pm 1.3$ & $6.8 \pm 0.06$ & $2.8 \pm 0.08$ & $2.1 \pm 0.01$ \\
\hline
\end{tabular}

Table 2 Content of heavy metals $\left(\mathrm{mg}^{\mathrm{kg}} \mathrm{kg}^{-1}\right)$ in soil substrate (extraction by aqua regia)

\begin{tabular}{lccccc}
\hline Locality & $\mathbf{Z n}$ & $\mathbf{C u}$ & $\mathbf{N i}$ & $\mathbf{P b}$ & $\mathbf{C d}$ \\
\hline Nitra & $62.4 \pm 2.4$ & $29.1 \pm 1.3$ & $40.3 \pm 1.7$ & $33.8 \pm 1.5$ & $2.2 \pm 0.04$ \\
\hline Limit $^{1}$ & 150 & 60 & 50 & 70 & 0.7 \\
\hline
\end{tabular}

${ }^{1}$ Limit value for aqua regia - Law No. 220/2004

\section{Sample preparation}

Garlic was divided into cloves and homogenized. $25 \mathrm{~g}$ of homogenized garlic were extracted in $50 \mathrm{ml}$ of $80 \%$ ethanol (Sigma - Aldrich Co, USA), which were shaken (shaker GFL 3006, $125 \mathrm{rpm}$ ) for sixteen hours. Samples were kept at laboratory room temperature in dark conditions until the analysis. Each determination was carried out in six replications.

\section{Determination of total polyphenols}

Total polyphenols content (TPC) was determined by the method according to Lachman et al. (2003). It is expressed as $\mathrm{mg}$ of gallic acid (Merck group, Germany) equivalent per $\mathrm{kg}$ of fresh matter. Total polyphenols content was determined using the Folin-Ciocalteu reagent (Merck group, Germany). $2.5 \mathrm{ml}$ of Folin-Ciocalteu reagent was added to $100 \mu \mathrm{l}$ extract to volumetric flask. The content was mixed. After 3 minutes, $5 \mathrm{ml} 20 \%$ solution of sodium carbonate (Merck group, Germany) was added. Then the volume was adjusted to $50 \mathrm{~m}$ with distilled water. After 2 hours, the samples were centrifuged (centrifuges UNIVERSAL 320, $15000 \mathrm{rpm}$, Germany) for 10 minutes. The absorbance was measured of the spectrophotometer Shimadzu UV/VIS - 1800 (Shimadzu, Japan) at $765 \mathrm{~nm}$. The concentration of polyphenols was calculated from a standard curve with known concentration of gallic acid.

\section{Determination of total sulfur compounds}

The determination of the total sulfur content is based on dry combustion in the presence of oxygen and allows for the quantitative conversion of sulfur to $\mathrm{SO}_{2}$ the elimination of other combustion products including water and the separation of the generated gases. $50 \mathrm{mg}$ of a lyophilized (Telstar Technologies LYOQUEST55, Spain) and homogenized sample is fired in a tin crucible with a $\mathrm{V}_{2} \mathrm{O}_{5}$ (Sigma - Aldrich Co, USA) catalyst in the elementar (Vario Macro Cube V 3.1.4, Elementar Analysensystem GmbH, Germany). After insertion of the crucible with the sample into the combustion tube, the oxygen stream produces a strong exothermic reaction, the temperature rises to $1250{ }^{\circ} \mathrm{C}$ and the sample is incinerated. Combustion products are conveyed along the combustion tube where the oxidation is complete. $\mathrm{SO}_{3}$ is reduced to $\mathrm{SO}_{2}$. The mixture of gases flows into the chromatographic column where the separation takes place. The gases are sent to the thermal conductivity detector where the electrical signals are processed by the software and provide the \% sulfur contained in the sample. Sulfanilamide (Sigma - Aldrich Co, USA) is used as the calibration standard (Šapčanin et al., 2013).

\section{Determination of antioxidant activity}

Antioxidant activity (AA) was measured according to Brand-Williams $\boldsymbol{e t}$ al (1995). The method is based on using DPPH ${ }^{-}$(2.2-diphenyl-1-picrylhydrazyl). $\mathrm{DPPH}^{\circ}$ (Sigma - Aldrich Co, USA) $(3.9 \mathrm{ml})$ was pipetted into the cuvette and the absorbance was measured using the spectrophotometer Shimadzu UV/VIS 1800 (Shimadzu, Japan) at $515.6 \mathrm{~nm}$. The measured value corresponds to the initial concentration of $\mathrm{DPPH}^{-}$solution at the time $\mathrm{A}_{0}$. Then $0.1 \mathrm{~cm}^{3}$ extract was added to start measuring dependence $A=f *(t)$. The content of cuvette was mixed and the absorbance was measured at 10 minutes in the same way as DPPH solution. The percentage of inhibition expresses how antioxidant compounds are able to remove $\mathrm{DPPH}^{\circ}$ radical at the given period of time.

Inhibition $(\%)=\left(\mathrm{A}_{0}-\mathrm{A}_{\mathrm{t}} / \mathrm{A}_{0}\right) \times 100$

\section{Statistical analysis}

Results were statistically evaluated by Analysis of Variance by one-way ANOVA (Multiple Range Tests) was performed, and the data were considered to be significantly different when $p<0.05$ using statistical software Statgraphics Centurion XVI.I (Statpoint Technologies, The Plains, Virginia, USA) and a correlation analysis (Microsoft Excel, Redmonde, Washington, USA) was used.

\section{RESULTS AND DISCUSSION}

The content of total polyphenols, total sulfur compounds and antioxidant activity in the studied varieties of garlic (Mojmír, Záhorský, Anton and Makoi) from area Nitra are presented in Table 3. The content of total polyphenols in the studied varieties is varied from $635.1 \pm 6.1 \mathrm{mg} \cdot \mathrm{kg}^{-1}$ to $742.0 \pm 5.2 \mathrm{mg} \cdot \mathrm{kg}^{-1}$. The highes level of total polyphenols was measured in Mojmír. In variety Makoi was detected the lowest value of total polyphenols content. In variety of Mojmír average level of TPC is 1.17-times higher than in variety Makoi. The studied varieties of garlic according to determined values of TPC can be arranged in following order: Mojmír >Anton > Záhorský >Makoi. Mahmutovic et al. (2009) indicated the total polyphenols content in the range $488 \mathrm{mg} \cdot \mathrm{kg}^{-1}$ to $800 \mathrm{mg} \cdot \mathrm{kg}^{-1}$, Bayili et al. (2011) measured TPC in garlic $741 \mathrm{mg} \cdot \mathrm{kg}^{-1}$, which is consistent with our results. Chekki et al. (2014) measured the lower level of TPC - 436 mg.kgalso Zakarova et al. (2014) - $450 \mathrm{mg} \cdot \mathrm{kg}^{-1}$, in comparison with this study.

The total sulfur content in the studied varieties of garlic ranges from $0.524 \pm$ $0.016 \%$ to $0.751 \pm 0.018 \%$ (Table 3 ). The highest level of TPC was measured in Mojmír. The lowest level of TSC was observed in Makoi. In variety Mojmír average level of TSC is 1.43-times higher than in Makoi. The determined quantity of total sulfur content in the samples can be arranged in the following order: Mojmír >Anton > Záhorský >Makoi. Benkeblia and Lanzotti (2007) indicated that the value of TSC in studied varieties of garlic move in wide range from $0.23 \%$ to $0.56 \%$. Mills et al. (2005) determined the total sulfur content with a value of up to $1 \%$. Muradic et al. (2010), measured the value TSC of garlic $0.63 \%$, which good correlate with the results of this work.

The value of antioxidant activity in the studied varieties of garlic ranges from $12.4 \pm 0.3 \%$ to $17.7 \pm 0.4 \%$ (Table 3 ). The statistically significant highest level of AA was measured in variety Mojmír. The lowest value of AA was detected in variety Makoi. The average level of AA in variety Mojmír is 1.43-times higher than in variety Makoi. According to determined values of AA the studied varieties of garlic can be arranged in the following order: Mojmír >Anton >Záhorský >Makoi. Sayin and Alkan (2015) indicate that the values of antioxidant activity is $16 \%$, which good correlate with the results of this work Rai et al. (2015) reported even a higher value of antioxidant activity in garlic $(21.5 \%)$. The lower value of antioxidant activity in garlic $7 \%$ was measured by Choi et al. (2014). 
Table 3 Average content of total polyphenols (TPC mg. $\mathrm{kg}^{-1}$ ), total sulphur (TSC \%) and antioxidant activity (AA \% inhibition)

\begin{tabular}{lccc}
\hline Variety & TPC $\left(\mathbf{m g ~ k g}^{-1}\right)$ & TSC (\%) & AA (\% inhibition) \\
\hline Mojmír & $742.0 \pm 5.2^{\mathrm{a}}$ & $0.751 \pm 0.018^{\mathrm{a}}$ & $17.7 \pm 0.4^{\mathrm{a}}$ \\
Záhorský & $665.2 \pm 6.6^{\mathrm{c}}$ & $0.567 \pm 0.014^{\mathrm{c}}$ & $14.5 \pm 0.4^{\mathrm{c}}$ \\
Anton & $678.3 \pm 5.7^{\mathrm{b}}$ & $0.593 \pm 0.017^{\mathrm{b}}$ & $16.0 \pm 0.5^{\mathrm{b}}$ \\
Makoi & $635.1 \pm 6.1^{\mathrm{d}}$ & $0.524 \pm 0.016^{\mathrm{d}}$ & $12.4 \pm 0.3^{\mathrm{d}}$ \\
$\mathrm{HD}_{0.05}$ & 7.1908 & 0.5109 & 0.0079 \\
\hline
\end{tabular}

Multiple Range Tests, Method: 95.0 percent LSD, Different letters (a, b, c and d) between the factors show statistically significant differences $(p<0.05)$

The relations among the total polyphenols content, total sulfur content and the antioxidant activity in studied varieties of garlic (Mojmír, Záhorský, Anton and Makoi) were evaluated (Figure 1-8). The coefficient of correlation ( $r=0.8831$ 0.9940 ) confirmed strong dependency between TPC, TSC and AA. The results are in good agreement with the findings of Ramkissoon et al. (2012) and Chen et al. (2013) confirmed correlations between total polyphenols content and antioxidant activity in garlic and other vegetable. Mahmutovic et al. (2014), who indicated correlations between total polyphenols content, total sulfur content and antioxidant activity in garlic.

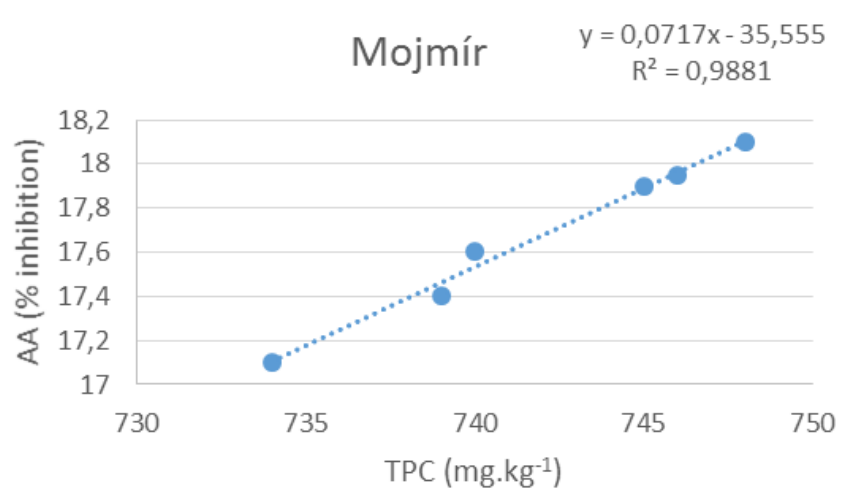

Figure 1 Relationship between TPC and AA in Mojmír

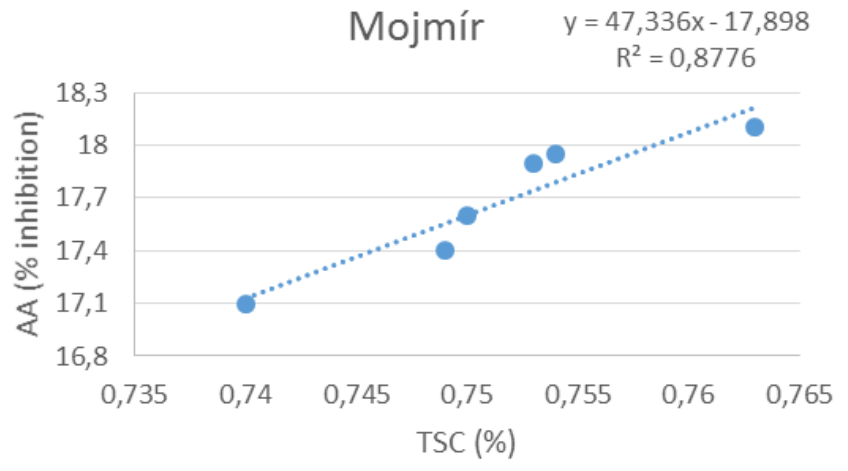

Figure 2 Relationship between TSC and AA in Mojmír

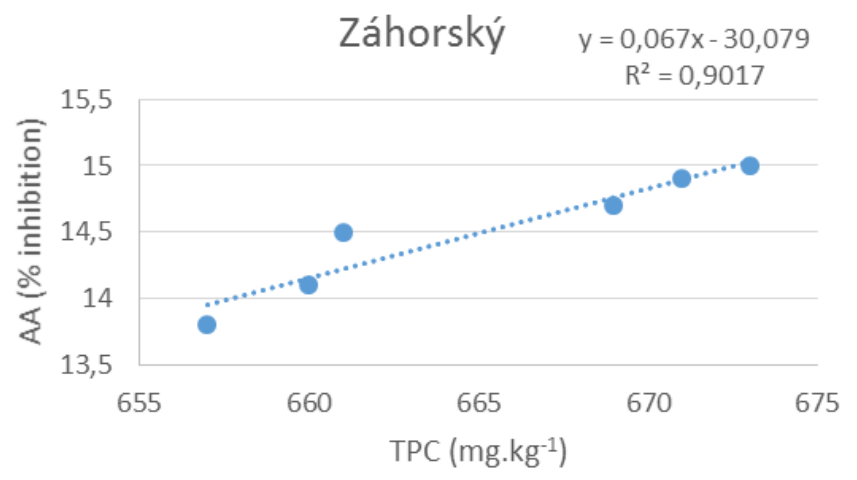

Figure 3 Relationship between TPC and AA in Záhorský

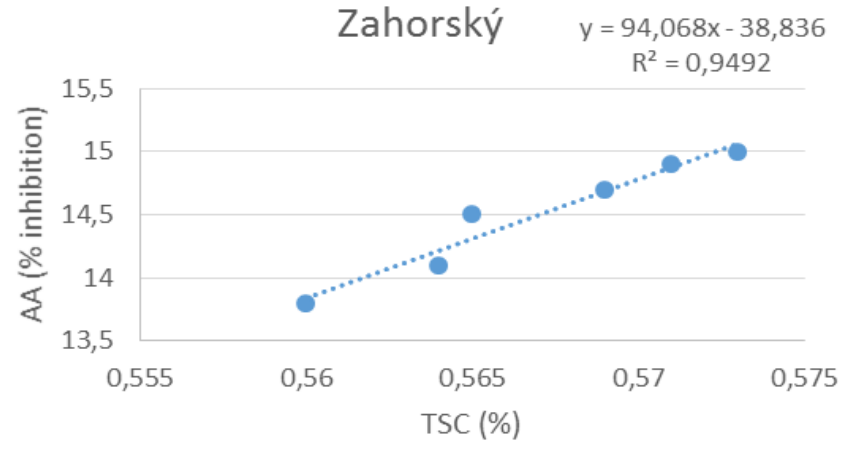

Figure 4 Relationship between TSC and AA in Záhorský

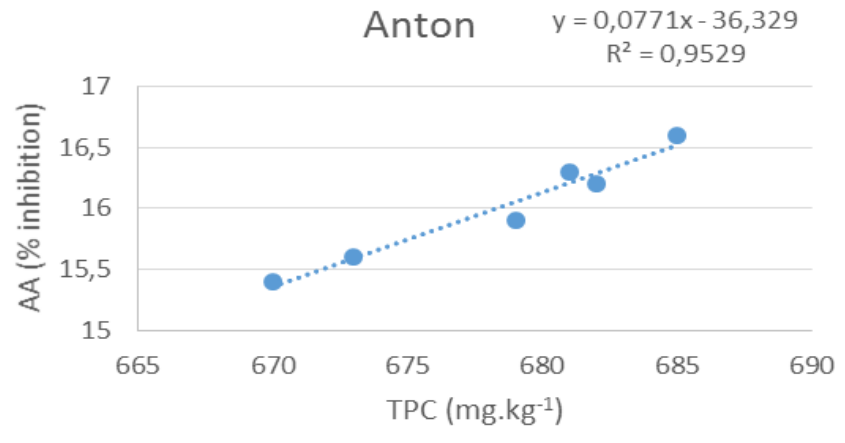

Figure 5 Relationship between TPC and AA in Anton

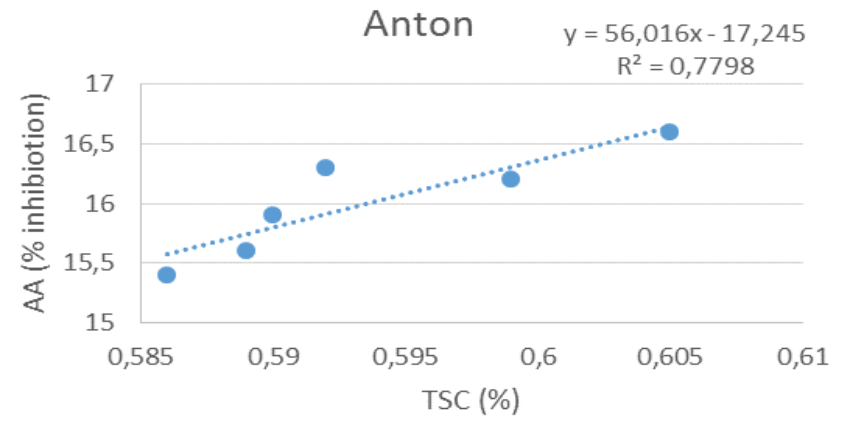

Figure 6 Relationship between TSC and AA in Anton

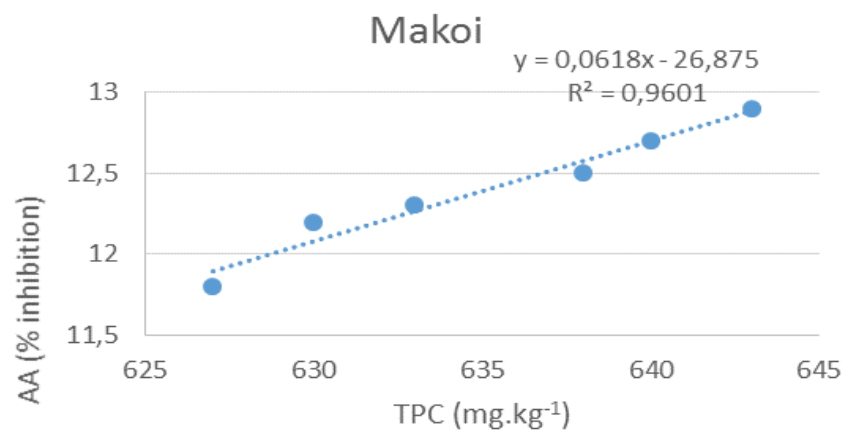

Figure 7 Relationship between TPC and AA in Makoi 


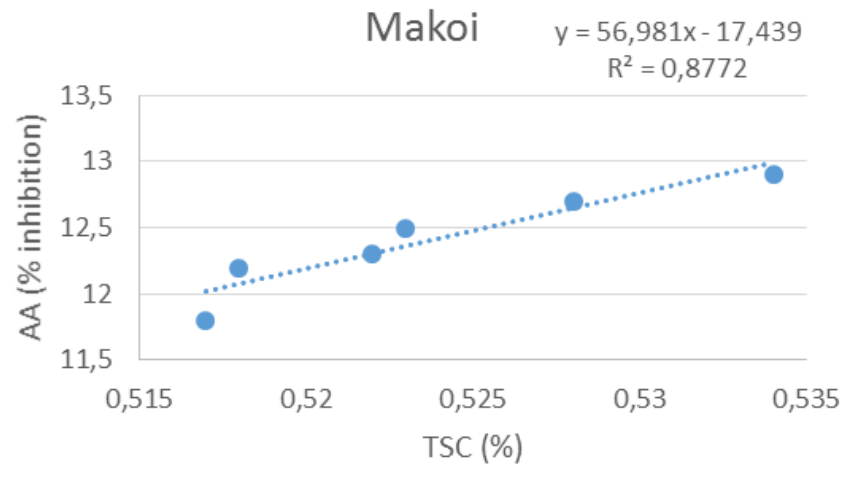

Figure 8 Relationship between TSC and AA in Makoi

\section{CONCLUSION}

The total polyphenols content, total sulfur content and antioxidant activity in studied varieties of garlic (Mojmír, Anton, Záhorský and Makoi), grown in locality Nitra were comparable with literature. The statistically significant differences in the monitored parameters were detected in the studied varieties of garlic. The highest value of total sulfur content, total polyphenols content and antioxidant activity was measured in variety Mojmír. The lowest value of the monitored indicators was determined in variety Makoi. The coefficient of correlation confirmed strong dependency between the total sulfur content, total content of polyphenols and the antioxidant activity. Health benefits of garlic depend on it's content of biologically-active compounds (polyphenols, sulfur compounds and antioxidant active ingredient), which differs between cultivars.

Acknowledgments: This work was supported by scientific grant VEGA 1/0139/17, VEGA 1/0114/18, KEGA 011SPU-4/2017.

\section{REFERENCES}

Act No. 220/2004 Coll. Of Laws of Slovak Republic. On the conservation and use of agricul- tural land, amending the Act No. 245/2003 Coll. on integrated pollution prevention and control, amending and supplementing of certain acts, as amended.

AMARAKOON, S., JAYASEKARA, D. 2017. A review on garlic (Allium sativum L.) as a functional food. Journal of Pharmacognosy and Phytochemistry, 6(6), 1777-1780. ISSN 2349-823

BAYILI, R. G., ABDOUL-LATIF, F., KONE, O. H., DIAO, M., BASSOLE, I. H. N., DICKO, M. H. 2011. Phenolic compounds and antioxidant activities in some fruits and vegetables from Burkina Faso. African Journal of Biotechnology, 10, 13543-13547. http://dx.doi.org/10.5897/AJB10.2010

BENKEBLIA, N., LANZOTTI, V. 2007. Allium Thiosulfinates: chemistry, biological properties and their potential utilization in food preservation. Food, 1, 2, 193-201.

BRAND-WILLIAMS, W., CUVELIER, M. E., BERSET, C. 1995. Use of a free radical method to evaluate antioxidant activity. Lebensmittel-Wissenschaft and Technologie, 28, 25-30. http://dx.doi.org/10.1016/S0023-6438(95)80008-5

CARDELLE-COBAS, A., SORIA, A.C., CORZO-MARTINEZ, M., VILLAMIEL, M. 2010. A comprehensive survey of garlic functionality. Garlic Consumption and Health. New York: Nova Scienc, Publishers, 1-60. http://dx.doi.org/10.13140/2.1.4992.6728

CHEKKI, R. Z., SNOUSSI, A., HAMROUNI, I., BOUZOUITA, N. 2014 Chemical composition, antibacterial and antioxidant activities of Tunisian garlic (Allium sativum) essential oil and ethanol extract. Mediterranean Journal of Chemistry, 3, 4, 947-956. http://dx.doi.org/10.13171/mjc.3.4.2014.09.07.11

CHEN, S., SHEN, X., CHENG, S., LI, P., DU, J., CHANG, Y., MENG, H. 2013. Evaluation of Garlic Cultivars for Polyphenolic Content and Antioxidant $\begin{array}{lllll}\text { Properties. } & \text { Plos } & \text { One } & \text { 11, 79730. }\end{array}$ http://dx.doi.org/10.1371/journal.pone.0079730

CHOI, S., CHA, H. S., LEE, Y. S. 2014. Physicochemical and antioxidant properties of black garlic. Molecules, 19, 16811-16823. http://dx.doi.org/10.3390/molecules191016811

CHUNG, L.Y. 2006. The antioxidant properties of garlic compou.nds: allyl cysteine, alliin, allicin, and allyl disulfide. Journal of Medicinal Food 9, 205-13. http://dx.doi.org/10.1089/jmf.2006.9.205

DIVYA, B., BUKKE, S., KUMAR, L.L., THYAGARAJU, K. 2017. The role of allium sativum (garlic) in various diseases and its health benefits: A comprehensive review. International Journal of Advanced Research, 5(8), 23205407. http://dx.doi.org/10.21474/IJAR01/5094.
GEBRESELEMA, G., MEBRAHTU, G. 2013. Medicinal values of garlic: A review . International Journal of Medicine and Medical Sciences 5(9), 401-408. http://dx.doi.org/10.5897/IJMMS2013.0960

HOUNSOME, N., HOUNSOME, B., TOMOS, D., EDWARDS-JONES G.2009. Changes in antioxidant compounds in white cabbage during winter storage. Postharvest Biology and Technology. 52, 173-179. ISSN 2068-7958 LACHMAN, J., PRONĚK, D., HEJTMANKOVÁ, A., DUDJAK, J., PIVEC, V., FAITOVÁ, K. 2003. Total polyphenol and main flavonoid antioxidant in different onion (Allium cepa L.) varieties. Horticultural Science, 30, 4, 142-147. http://dx.doi.org/10.17221/3876-HORTSCI

MAHMUTOVIC, O., MUJIC, E., TOROMANOVIC, J., MUSTOVIC, F., MURADIC, S., HUSEINOVIC, S., SOFIC, E. 2009. Comparative analysis of total phenols and sulfur content in some plant organs of ramsons and two garlic species. Planta Medica, 75, 43. http://dx.doi.org/10.1055/s-0029-1234522

MAHMUTOVIC, O., TAHIROVIC, I., COPRA, A., KARIC, L. 2014. Correlation of Total Secondary Sulfur Compounds, Total Phenols and Antioxidant Capacity in the Ramsons and Garlic. British Journal of Pharmaceutical Research, 4, 23, 2662-2669. http://dx.doi.org/BJPR/2014/13977 MILLS, S., BONE, K., PHYTO, D. 2005. The Essential Guide to Herbal Safety USA: Elsevier Churchill Livingstone, 687.

MURADIC, S., KARACIC, D., MAHMUTOVIC, O., MUTOVIC, F., SOFIC, E., KROYER, G. 2010. Total sulphur and organosulphur and organosulphur compounds in garlic and ramsons plant organs at the end of vegetative period Planta Medica, 76, 292. http://dx.doi.org/10.1055/s-0030-1264590

RAHMAN, M.S. 2007. Allicin and other functional active components in garlic: Health benefits and bioavailability. International Journal of Food Properties, 10, 245-268. https://dx.doi.org/10.1080/10942910601113327

RAI, CH., BHATTACHARJEE, S., NANDI, N., BHATTACHARYYA, S. 2015 Influence of blanching on antioxidant and antimicrobial activities of raw garlic (Allium sativum). Indo American Journal of Pharmaceutical sciences, 2, 6 , 1071-1076. ISSN 2349-7750

RAMKISSOON, J. S., MAHOMOODALLY, M. F., AHMED, N., SUBRATTY, A. H. 2012. Relationship between total phenolic content, antioxidant potencial, and antiglycation abilities of common culinary herbs and spices. Journal of Medical Food, 15, 12, 1116-1123. http://dx.doi.org/10.1089/JMF.2012.0113

SAYIN, F. K., ALKAN, S. B. 2015. The effect of pickling on total phenolic content and antioxidant activity of 10 vegetables. Journal of Food and Health Science, 1, 3, 135-141. http://dx.doi.org/10.3153/JFHS15013

ŠAPČANIN, A., JANCAN, G., PAZALJA, M., KRESIC, D., PEHLIC, E., UZUNOVIC, A. 2013. Determination of total sulphur content in biological samples by using high performance ion chromatography and elemental analysis. Bulletiin of the Chemists and Technologists of Bosnia and Herzegovina, 41, 1114. ISSN: 2232-7266

TEPE, B., SOKMEN, M., AKPULAT , HA., SOKMEN, A. 2005. In vitro antioxidant activities of the methanol extracts of five Allium species from $\begin{array}{llll}\text { Turkey. Food } & \text { Chemistry. } & \text { 82, }\end{array}$ http://dx.doi.org/10.1016/j.foodchem.2004.07.016

YADAV, A., KUMARI, R., YADAV, A., PRABHA, S. 2016. Antioxidant and its functions in human body - A Review. Research in Environment and Life Sciences. 9(11), 1328-1331. ISSN: 0974-4908

ZAKAROVA, A., SEO, J. Y., KIM, H. Y., KIM, J. H., SHIN, J. H., CHO, K. M., LEE, CH. H., KIM, J. S. 2014. Garlic sprouting is associated with increased antioxidant activity and concomitant changes in the metabolite profile. Journal of Agricultural and Food Chemistry, 62, 8, 1875-1880 http://dx.doi.org/10.1021/jf500603v 